\title{
СТАН ВЕГЕТАТИВНОГО ГОМЕОСТАЗУ В ДІТЕЙ ШКІЛЬНОГО ВІКУ 3 РІЗНИМ РІВНЕМ СОМАТИЧНОГО ЗДОРОВ'Я
}

\author{
Козакевич В. К., Зюзіна Л. С.
}

\section{ВСТУП}

На різних етапах розвитку суспільства вивченню проблем здоров'я завжди приділялась велика увага. На початку XXI століття проблеми здоров'я матері та дитини були включені Організацією Об'єднаних Націй у «Цілі розвитку тисячоліття». Свропейський регіональний комітет ВООЗ прийняв у вересні 2005 року Європейську стратегію «Здоров'я і розвиток дітей і підлітків», де Україна визначена пілотним регіоном для впровадження Стратегії ${ }^{1}$. Дані численних досліджень показують, що джерело виникнення відмінностей у здоров”ї дорослих треба шукати в їхньому дитинстві ${ }^{2,3,4}$.

Стан здоров'я дітей $\epsilon$ інтегральним показником загального благополуччя суспільства і тонким індикатором усіх соціальних та екологічних негараздів ${ }^{5,6,7,8}$. Статистичні дані та результати спеціальних досліджень свідчать, що в Україні впродовж останніх років зберігається стійка негативна динаміка основних показників

${ }^{1}$ Европейская стратегия «Здоровье и развитие детей и подростков». Копенгаген: ЕРБ ВОЗ, 2005. С. 1.

2 Показники та соціальний контекст формування здоров'я підлітків: монографія / Балакірєва О.М., Бондар Т.В., Павлова Д.М. та ін. ; відп. ред. О.М. Балакірєва, Київ : ЮНІСЕФ, Укр. ін-т соц. досліджень ім. О. Яременка, 2014. С. 5.

3 Марушко Ю.В., Гищак Т.В. Проблема діагностики і корекції зниженої толерантності до фізичного навантаження у дітей шкільного віку. Современная педиатрия. 2014. № 7(63). С. 34.

${ }^{4}$ BenShlomo Y., Kuh D. A life course approach to chronic disease epidemiology: conceptual models, empirical challenges and interdisplinary perspectives. Int. J. Epidemiol. 2002. № 31. P. 285.

5 Козакевич В.К., Зюзіна Л.С. Нові підходи до оцінки стану здоров'я дітей шкільного віку. Современная педиатрия. 2016. № 4 (76). С. 44.

6 Роль соціально-економічних факторів у формуванні рівня соматичного здоров'я дітей шкільного віку / В.К. Козакевич та ін. Wiadomości Lekarskie. 2018. tom LXXI. nr 3 cz I. C. 537.

${ }^{7}$ Медико-социальные особенности состояния здоровья школьников в Украине / С.Л. Няньковский та ін. Georgian Medical News. 2014. № 5(230). С. 61.

${ }^{8}$ Пономарьова Л.І. Особливості формування здоров'я сучасних школярів на різних етапах навчання. Здоровье ребенка. 2014. № 2(53). С. 35. 
здоров'я дітей $9,10,11,12$. Особливу й досить складну соціальну групу представляють діти шкільного віку. Майже 90\% дітей шкільного віку мають відхилення в стані здоров'я, понад 50\% - мають незадовільну фізичну підготовку ${ }^{13}$. Серед причин погіршення стану здоров'я дітей шкільного віку вчені вважають збільшення шкільного навантаження та зменшення фізичної активності, що веде до зниження компенсаторно-резервних можливостей організму дитини ${ }^{14,15,16,17,18}$.

Тому для вимірювання та оцінки рівня здоров'я нині все ширше використовується «теорія адаптації». Знання закономірностей функціонування фізіологічної системи дає можливість управляти адаптаційним процесом, вносячи корективи в ті ланки, що дозволяють такі втручання, обмежуючи коливання фізіологічних параметрів у безпечному щодо розвитку патологій діапазоні ${ }^{19}$.

${ }^{9}$ Барыкина С.В. Здоровьесбережение: системность мер обеспечения. Матер. III Всеросс. конгресса «Актуальные проблемы здоровья детей и подростков и пути их решения». Москва: Издательство НЦЗД РАМН, 2012. С. 59.

${ }^{10}$ Healthy Living Cambridge Kids: a community-based participatory effort to promote healthy weightand fitness / V.R. Chomitz et al. Obesity.Silver Spring. 2010. № 18(1). P. 45.

${ }^{11}$ Retter T.D. School-Based Health Centers in Pediatric Practice. Council on School health Pediatrics. 2012. Vol. 129. P. 387.

12 Thompson R.T., Meslin E.M., Braitstein P.K. The vulnerabilities of orphaned children participating in research: a critical review and factors for consideration for participation in biomedical and behavioral research. J Empir Res Hum Res Ethics. 2012. Vol. 7(4). P. 56.

13 Москаленко Н.В., Єлісєєва Д.С. Аналіз рівня соматичного здоров'я дітей старшого шкільного віку. Вісник Чернігівського національного педагогічного університету. 2014. № 118(3). С. 189.

14 Бабій І.Л., Величко В.І., Венгер Я.І. Адаптаційні можливості школярів. Здоровье ребенка. 2011. № 8(35). С. 20.

${ }_{15}$ Состояние механизмов адаптации к учебной нагрузке старшеклассников с разным уровнем профессиональной готовности / Г.Н. Даниленко и др. Здоровье ребенка. 2013. № 3(46). С. 35.

${ }^{16}$ Кузюк Л.Г., Маковкін Ю.А, Ігнатова Т.Б. Адаптаційні можливості організму з урахуванням морфофункціонального розвитку дітей шкільного віку. Современная педиатрия. 2011. № 1(35). С. 95.

${ }^{17}$ Сергета І.В., Мостова О.П. Особливості перебігу процесів психофізіологічної адаптації та формування психофізіологічних функцій організму учнів сучасної школи. Актуальні проблеми транспортної медицини. 2013. Т. 32. № 2. С. 84.

${ }^{18}$ Moderate-to-vigorous physical activity fromages 9 to 15 years / P.R. Nader et al. Jama. 2008. № 300(3). Р. 295.

${ }^{19}$ Баевский Р.М., Иванов Г.Г. Вариабельность сердечного ритма: теоретические аспекты и возможности клинического применения. Москва: Медицина, 2000. С. 2. 
За даною концепцією початок захворювання визначається як явище адаптаційного порушення у функціональних системах, а сама хвороба - як результат виснаження адаптаційних механізмів ${ }^{20,21,22}$.

Дослідження вегетативного гомеостазу в дітей $\epsilon$ одним зі складників оцінки адаптаційних механізмів організму в умовах фізичного та розумового навантаження. Взаємодія симпатичного i парасимпатичного відділів вегетативної нервової системи забезпечує здійснення оптимальної адаптації організму до мінливих умов внутрішнього та зовнішнього середовища ${ }^{23,24}$. Вивчення вихідного вегетативного тонусу і вегетативної реактивності дозволяе скласти уявлення про особливості вегетативної регуляції серцево-судинної системи й організму в цілому.

У літературі є повідомлення, що інформація про стан вегетативної нервової системи у дітей допомагає вивчити різноманітні аспекти шкільної пристосованості, прогнозувати можливі порушення у стані здоров'я, а також дозволяє лікарю-педіатру більш ефективно проводити лікування окремих патологій ${ }^{25,26}$.

Однак у доступній нам літературі ми не знайшли інформації про залежність стану нейрогуморальних механізмів регуляції серцевої діяльності від рівня енергозабезпечення організму, відсутні розробки критеріїв діагностики ранніх ознак порушень адаптаційнопристосувальних механізмів та виявлення змін в організмі дитини на донозологічному рівні.

${ }^{20}$ Апанасенко Г.Л., Козакевич В.К. Оценка физического здоровья детей и подростков. Медичний всесвіт. 2004. Т. 4. С. 68.

${ }_{21}$ Гозак С.В., Єлізарова О.Т. До питання оцінки адаптаційно-резервних можливостей організму дітей шкільного віку в гігієнічних дослідженнях. Гігієна населених місизь. 2012. № 59. С. 285.

22 Оцінка стану здоров'я школярів загальноосвітніх навчальних закладів різного типу / I.О. Калиниченко та ін. Вісник Сум ДУ. Серія 172 «Медицина». 2012. № 1. С. 172.

${ }_{23}$ Баевский Р.М., Черникова А.Г. К проблеме физиологической нормы: математическая модель функциональных состояний на основе анализа вариабельности сердечного ритма. Авиакосмическая и экологическая медицина. 2002. № 5. C. 34 .

${ }^{24}$ Коровіна Л. ., Запорожець Т.М., Козакевич В.К. Вплив екзогенних чинників на соматичне здоров'я та автономну нервову регуляцію у дітей та молоді: монографія. Полтава : «Освітаінфоком», 2019. С. 1.

25 Вакуленко Л.І. Вегетативний статус у дітей із хронічним пієлонефритом на початкових стадіях хронічної хвороби нирок. Здоров'я дитини. 2019. Т. 14. № 2. С. 81.

${ }^{26}$ Вегетативні дисфункції у дітей. Пароксизмальна вегетативна недостатність / В.Г. Майданнік и др. Київ: Логос, 2017. С. 12. 
Тому порівняльне вивчення стану вегетативного гомеостазу дітей 3 різним рівнем соматичного здоров'я, визначеним за енергопотенціалом біосистеми, $\epsilon$ актуальним, оскільки стан вегетативної нервової системи відбиває ступінь адаптованості організму, яка $\epsilon$ показником його індивідуального здоров'я ${ }^{27,28}$. А реальний стан здоров'я дітей та підлітків України вимагає пошуку найбільш адекватних і ефективних заходів, насамперед профілактичних, які б надали можливості виявити зміни в стані здоров'я на донозологічному рівні.

\section{1. Соматичне здоров'я дітей шкільного віку за показниками компенсаторно-резервних можливостей організму: власне дослідження}

Нами було вивчено стан соматичного (фізичного) здоров'я 294-х дітей м. Полтави (139 хлопчиків та 155 дівчаток) віком від 12 до 14-ти років ${ }^{29}$. Антропометричні вимірювання здійснювали за загальноприйнятою методикою. Соматотип визначали відповідно до схеми Р.К. Дорохова та I.І. Бахраха 3 виділенням у дітей трьох соматотипів: мікросоматичного, мезосоматичного та макросоматичного $^{30}$. Віднесення дитини до одного із цих соматотипів проводилось згідно із сумою номерів «коридорів» центильної шкали, отриманих для довжини тіла, обводу грудної клітки та маси тіла. За суми балів до 10 дитину відносили до мікросоматичного типу, за суми від 11 до 15 балів - до мезосоматичного, за суми від 16 до 21 бала - до макросоматичного соматотипу.

Діагностика рівня здоров'я - це перший крок у профілактичну медицину $^{32,31}$. Нами проведено визначення рівня соматичного здоров'я (далі - РС3) за методикою кількісної експрес-оцінки Г.Л. Апанасенко. Основою даної методики були показники

${ }^{27}$ Баевский Р.М., Иванов Г.Г. Вариабельность сердечного ритма: теоретические аспекты и возможности клинического применения. Москва: Медицина, 2000. С. 1.

${ }^{28}$ Баевский P.M., Черникова А.Г. К проблеме физиологической нормы: математическая модель функциональных состояний на основе анализа вариабельности сердечного ритма. Авиакосмическая и экологическая медицина. 2002. № 5. С. 34.

${ }^{29}$ Наказ МO3 України від 13.09.2013 р. № 802 «ро затвердження критеріїв оцінки фізичного розвитку дітей шкільного віку».

30 Оцінка стану здоров'я школярів загальноосвітніх навчальних закладів різного типу / І.О. Калиниченко та ін. Вісник Сум ДУ. Серія 172 «Медицина». 2012. № 1. С. 172-177.

${ }^{31}$ Апанасенко Г.Л., Козакевич В.К. Оценка физического здоровья детей и подростков. Медичний всесвіт. 2004. Т. 4. С. 68. 
антропометрії (зріст, маса тіла), життєва ємність легень, показники динамометрії, а також стан серцево-судинної системи ${ }^{32}$. Критерієм резерву й економізації функції серцево-судинної системи $є$ два показники: індекс Руф'є (далі - IP) та індекс «подвійного добутку» (далі - ІПД) у спокої (індекс Робінсона).

Величину індексу Руф'є визначали за формулою:

$$
\mathrm{IP}=\frac{4\left(\mathrm{P}_{1}+\mathrm{P}_{2}+\mathrm{P}_{3}\right)-200}{10},
$$

де: $\mathrm{P}_{1}$ - пульс за 15 сек. у спокої;

$\mathrm{P}_{2}$ - пульс за перші 15 сек. після 30 присідань за 45 сек.;

$\mathrm{P}_{3}$ - пульс за останні 15 сек. першої хвилини періоду відновлення.

Величину індексу Робінсона (ІПД) визначали за формулою:

$$
\text { ІПД }=\frac{\text { ЧСС }_{\Pi} \cdot \mathrm{ATC}}{100},
$$

де: ЧСС - частота серцевих скорочень за 1 хвилину;

АТС - систолічний артеріальний тиск, мм. рт. ст.

Ми також оцінювали співвідношення маси тіла до довжини за спеціальними таблицями. Усі показники розраховували та проводили оцінку в балах окремо для хлопчиків та дівчаток. Загальну оцінку РСЗ визначали сумою балів, що відповідала певному рівню аеробного енергопотенціалу ${ }^{32}$.

Результати проведених досліджень показали, що обстежені діти складають неоднорідну за рівнем функціонування енергозабезпечувальних систем групу. Було встановлено, що високий та вище середнього РСЗ мали лише $4,6 \pm 0,9 \%$ та $6,6 \pm 1,1 \%$ обстежених

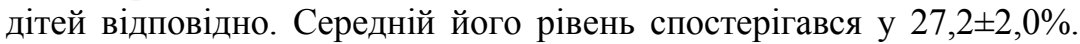
Понад 60\% дітей мали низький та нижче середнього РС3 (рис. 1).

Вивчення РС3 у віковому аспекті показало, що в популяції обстежених дітей відмічалися вікові періоди його помітного погіршання. У дівчаток цей період припадає на 12 років, коли РСЗ у них виявився значно нижчим, ніж у групі хлопчиків цього віку

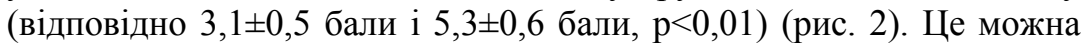
пояснити більш раннім початком пубертату та фізіологічною перебудовою організму дівчаток ${ }^{33}$. Суттєве погіршення стану соматичного здоров'я хлопчиків відмічалося у 13 років, що корелює

${ }^{32}$ Апанасенко Г.Л. Эволюция биоэнергетики и здоровье человека. Петрополис, 1992. C. 5.

${ }^{33}$ Козакевич В.К., Зюзіна Л.С. Нові підходи до оцінки стану здоров'я дітей шкільного віку. Современная педиатрия. 2016. № 4 (76). С. 44-46. 
зі змінами у фізичному розвитку. Чим більшою була маса тіла, тим нижчим був РС3 ( $\mathrm{r}=-0,31, \mathrm{p}<0,001)$.
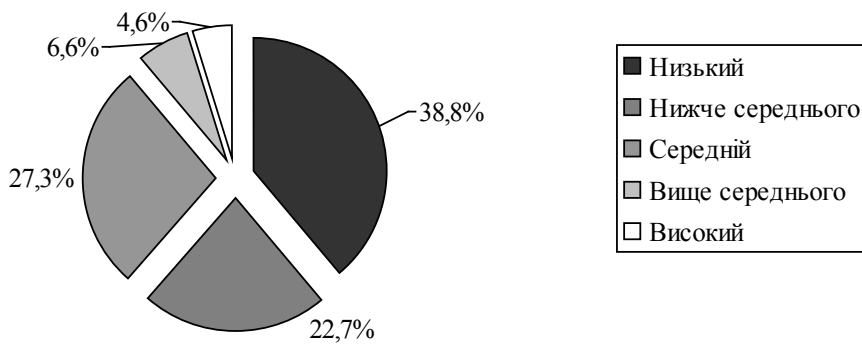

Рис. 1. Розподіл дітей за рівнем соматичного здоров'я

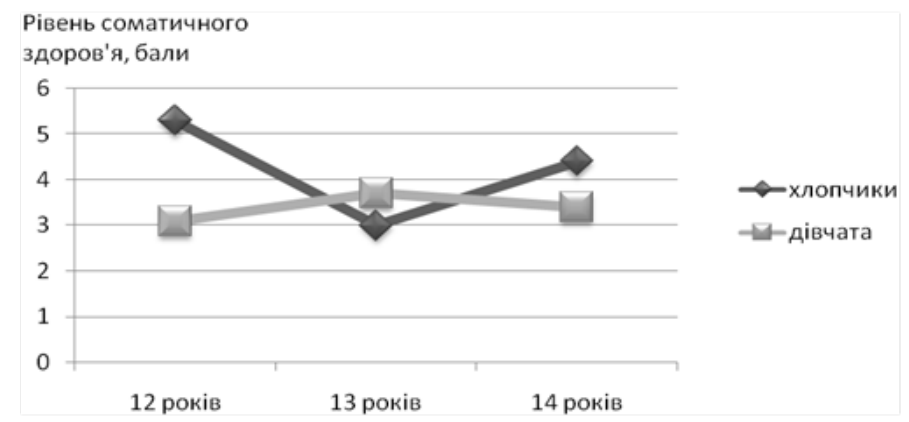

Рис. 2. Статева різниця рівня соматичного здоров'я (бали)

Нами проаналізовано РСЗ школярів різних віково-статевих груп з урахуванням соматотипу. За результатами проведеного порівняльного аналізу встановлено, що найбільші відхилення від норми у стані соматичного здоров'я спостерігаються у дітей 3 макросоматичним соматотипом, більшість яких має низький та нижче середнього РСЗ $68,5 \%$ та 14,7\% відповідно, середній РС3 мають 13,5\%, вище середнього РС3 - лише 3,4\% обстежених дітей (рис. 3). Дітей з високим РСЗ серед дітей з макросоматичним соматотипом взагалі не було.

Крім того, кожна друга дитина з макросоматичним соматотипом мала дисгармонійний фізичний розвиток за рахунок надлишкової маси тіла чи високого зросту. 


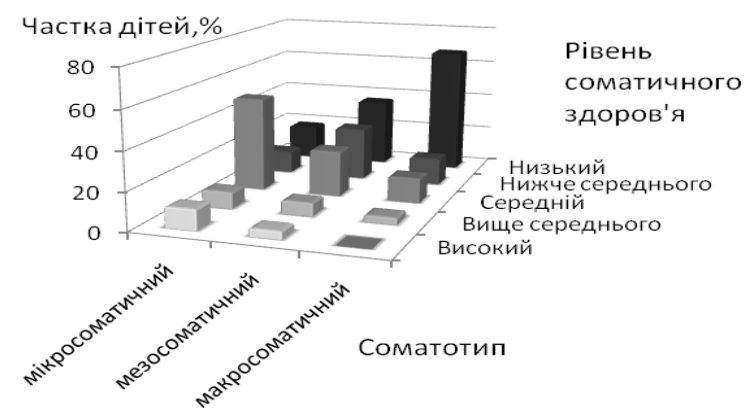

Рис. 3. Показники рівня соматичного здоров'я у дітей з різнім соматотипом (\%):

1 -мікросоматичний соматотип; 2 -мезосоматичний соматотип; 3 -макросоматичний соматотип

Серед дітей 3 мезосоматичним та мікросоматичним соматотипами низький РС3 спостерігався лише у 36,3\% та 18,5\% обстежених відповідно. Серед усієї когорти обстежених дітей високий PC3 був притаманний тільки дітям 3 мезосоматичним та мікросоматичним соматотипами $-4,1 \%$ та $10,9 \%$ відповідно.

Отримані дані підтверджені проведеним кореляційним аналізом, який виявив вірогідні негативні зв'язки між РС3 та соматотипом $(\mathrm{r}=-0,32, \mathrm{p}<0,001)$. Це свідчить, що макросоматичний тип тілобудови дитини супроводжуються погіршенням енергозабезпечення організму.

\section{2. Стан вихідного вегетативного тонусу в дітей}

3 різним рівнем соматичного здоров'я: власне дослідження

Функціональний стан серцево-судинної системи є індикатором адаптаційної діяльності цілого організму і показником активності нейровегетативних реакцій ${ }^{34}$. Оскільки серцево-судинна система може розглядатися як індикатор адаптаційно-пристосувальної діяльності організму, важливим є вивчення аналізу змін ритму серця як універсальної реакції організму у відповідь на будь-яке навантаження ${ }^{35,36}$.

${ }^{34}$ Баевский Р.М., Иванов Г.Г. Вариабельность сердечного ритма: теоретические аспекты и возможности клинического применения. Москва: Медицина, 2000. С. 1.

${ }^{35}$ Баевский Р.М., Черникова А.Г. К проблеме физиологической нормы: математическая модель функциональных состояний на основе анализа вариабельности сердечного ритма. Авиакосмическая и экологическая медицина. 2002. № 5. С. 34.

${ }^{36}$ Вакуленко Л.І. Вегетативний статус у дітей із хронічним пієлонефритом на початкових стадіях хронічної хвороби нирок. Здоров'я дитини. 2019. Т. 14. № 2. С. 81. 
Стан вегетативної нервової системи (далі - ВНС) оцінювали згідно 3 даними вихідного вегетативного тонусу, вегетативної реактивності, вегетативного забезпечення діяльності, отриманими за результатами методу кардіоінтервалографії.

Проведений комплексний аналіз кардіоінтервалограм (далі - КІГ) дозволив визначити різний рівень функціонування вегетативної нервової системи обстежених дітей (рис. 4).

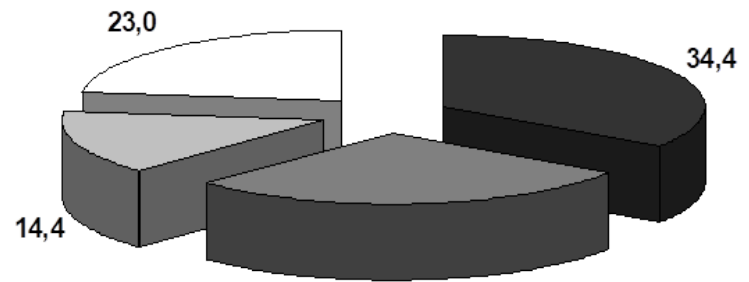

28,2

चйтонія $\square$ ваготонія $\square$ симпатикотонія $\square$ гіперсимпатикотонія

Рис. 4. Структура вихідного вегетативного тонусу в обстежених дітей

Вихідний вегетативний тонус (далі - ВВТ) ейтонія - збалансований стан регуляторних систем вегетативної нервової системи спостерігався нами у $34,4 \pm 3,1 \%$ дітей, ВВТ ваготонія - у $28,3 \pm 3,0 \%$ обстежених, помірна перевага тонусу симпатичної ланки вегетатив-

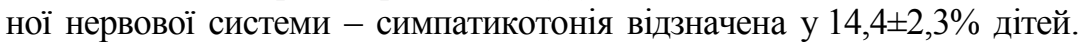
Гіперсимпатикотонія, яка дає підставу констатувати перенапруження регуляторних систем, виявлена у $23,0 \pm 2,8 \%$ обстежених дітей.

Нами проаналізовано залежність вихідного вегетативного тонусу від РСЗ, що дозволило виявити ряд закономірностей (рис. 5).

Серед обстежених дітей було 74 з низьким РС3, 58 - 3 нижче середнього, 64 - із середнім, 22 - 3 вище середнього та 12 дітей 3 високим РСЗ.

Як видно з рис 5, найбільші відхилення від норми у стані ВНС спостерігалися в дітей з низьким РСЗ. Так, ейтонія була виявлена лише у 27,4 $\pm 5,3 \%$ дітей 3 низьким РС3, тоді як кількість обстежених дітей 3 гіперсимпатикотонією становила $38,4 \pm 5,7 \%$ проти $6,3 \pm 3,1 \%$ у групі дітей із середнім РС3 $(\mathrm{p}<0,01)$. А в групі дітей з високим i вище середнього РСЗ симпатикотонічний та гіперсимпатикотонічний BВТ взагалі не спостерігався. 3 наведених на рис 5 даних видно, що з підвищенням РС3 збільшується частка дітей з ваготонією, яка 
в групі дітей $з$ високим РС3 становила 83,3 $\pm 11,2 \%$ проти $12,3 \pm 3,9 \%$ у групі дітей з низьким РС3 ( $<<0,001)$.

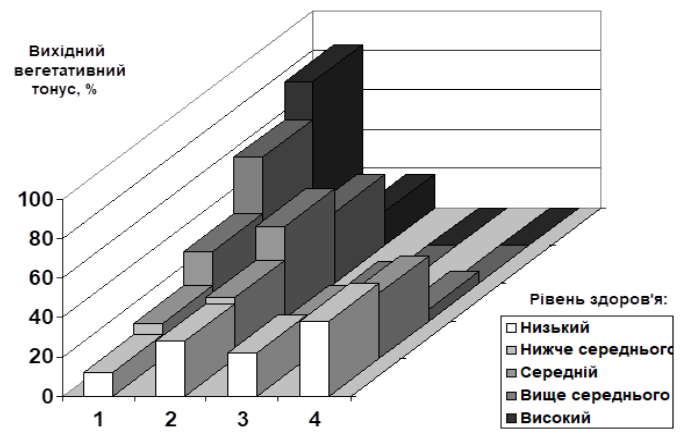

Рис. 5. Вихідний вегетативний тонус у дітей з різним рівнем соматичного здоров'я:

Вихідний вегетативний тонус: 1 - ваготонія, 2 - ейтонія, 3 - симпатикотонія, 4 - гіперсимпатикотонія.

Також нами був проведений аналіз ВВТ у залежності від соматотипу дитини. Серед обстежених дітей 3 мезосоматичним соматотипом було 154, 3 мікросоматичним - 42, 3 макросоматичним 34 дитини.

Проведене дослідження виявило, що частка дітей із симпатикотонічним ВВТ серед дітей 3 макросоматичним соматотипом виявилась вірогідно вищою, ніж з мікросоматичним соматотипом $(26,5 \pm 7,7 \%$ та $7,1 \pm 4,0 \%$ відповідно, $<<0,01)$ (рис. 6). Отримані нами дані не збігаються 3 літературними даними, де наведені зворотні залежності.

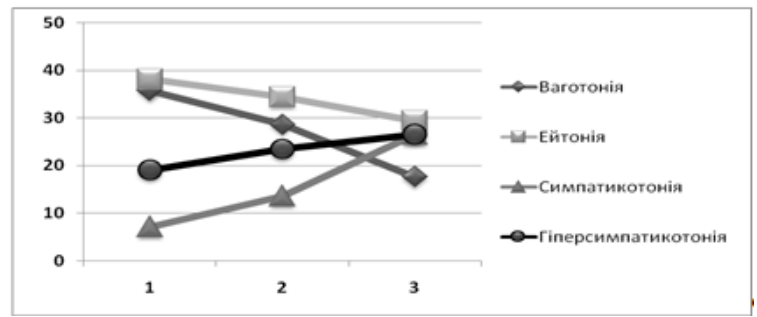

Рис. 5. Вихідний вегетативний тонус у дітей 3 різним соматотипом:

1 -мікросоматичний соматотип, 2 -мезосоматичний соматотип, 3 -макросоматичний соматотип. 
Проведене дослідження виявило переважання тонусу симпатичного відділу ВНС у дітей з низьким РС3, на що вказує вірогідне зменшення варіаційного розмаху $(\Delta x)$ та моди $(\mathrm{Mo})$ і збільшення амплітуди моди (AМо) порівняно 3 дітьми із середнім рівнем соматичного здоров'я (рис. 6-8). Вірогідне збільшення інтегрального індексу напруження (IH), індексу вегетативної рівноваги (IBP) та індексу вегетативного показника ритму (ВПР) цієї категорії дітей характеризують напруження центрального контуру регуляції (рис. 9-11). Цей стан можна охарактеризувати як стан незадовільної адаптації зі зменшенням рівня функціонування біосистеми, з розладом окремих іiі елементів і розвитком втомлюваності ${ }^{37}$.

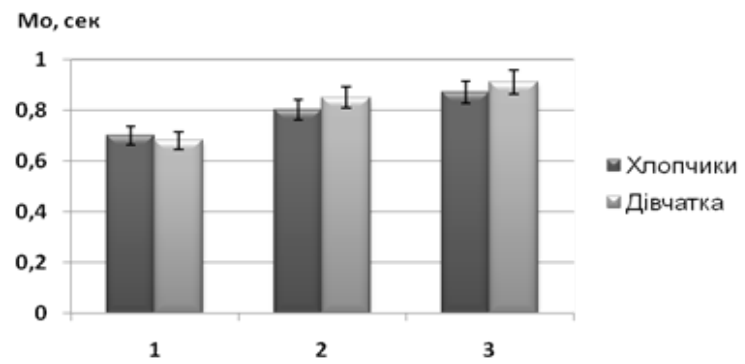

Рис. 6. Значення моди в дітей 3 різним рівнем соматичного здоров'я; рівень соматичного здоров'я:

1 - низький, 2 - середній, 3 - високий

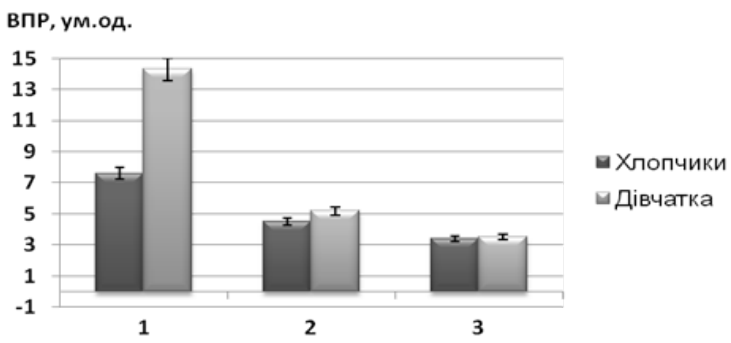

Рис. 7. Значення варіаційного розмаху в дітей з різним рівнем соматичного здоров'я; рівень соматичного здоров'я:

1 - низький, 2 - середній, 3 - високий

${ }^{37}$ Вейн А.М., Вознесенская Т.Г., Воробьева О.В. Вегетативные расстройства. Клиника, диагностика, лечение / под ред. А.М. Вейна. Москва: ООО «Медицинское информационное агенство», 2003. С. 25. 


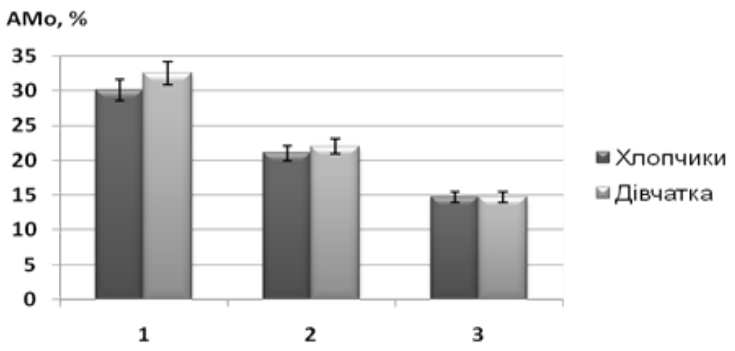

Рис. 8. Значення амплітуди моди в дітей з різним рівнем соматичного здоров'я; рівень соматичного здоров'я: 1 - низький, 2 - середній, 3 - високий

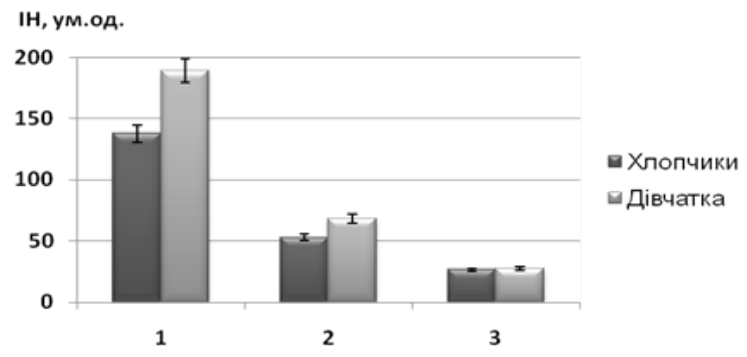

Рис. 9. Значення індексу напруження в дітей з різним рівнем соматичного здоров'я; рівень соматичного здоров'я:

1 - низький, 2 - середній, 3 - високий

ВПР, ум.од.

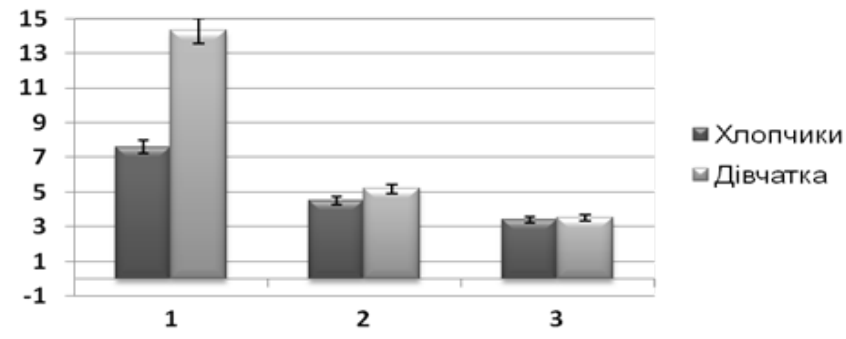

Рис. 10. Значення вегетативного показника ритму

в дітей з різним рівнем соматичного здоров'я; рівень соматичного здоров'я:

1 - низький, 2 - середній, 3 - високий 


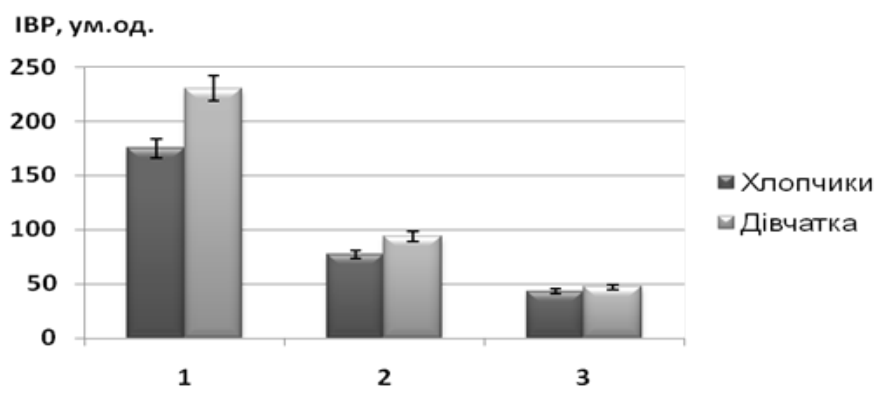

Рис. 11. Значення індексу вегетативної рівноваги в дітей 3 різним рівнем соматичного здоров'я; рівень соматичного здоров'я:

1 - низький, 2 - середній, 3 - високий

Таким чином, в умовах спокою нормотонічний та помірно ваготонічний типи ВНС свідчать про оптимальний стан центральних та автономних механізмів регуляції, а дітей із симпатикотонічним i гіперсимпатикотонічним ВBT необхідно віднести до групи ризику щодо порушень стану соматичного здоров'я з метою своєчасного проведення профілактичних заходів.

\section{3. Вегетативна реактивність у дітей з різним рівнем} соматичного здоров'я: власне дослідження

У подальших дослідженнях ми проаналізували вегетативну реактивність (далі - ВР), яка характеризує спрямованість і ступінь змін вегетативних реакцій на зовнішні та внутрішні подразники ${ }^{38}$.

Обстежено 129 дітей віком 12-14 років. Комплексний аналіз отриманих даних виявив, що лише $45,0 \pm 4,4 \%$ обстежених мали нормальну ВР. У $55,0 \%$ визначено порушення ВР $(41,1 \pm 4,3 \%$ мали

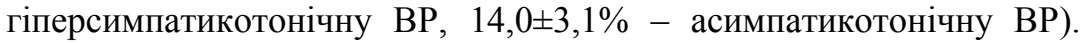
Оцінка ВР у залежності від ВВТ дозволила встановити особливості адаптаційних реакцій обстежених дітей (табл. 1).

Збалансований рівень регуляторних систем ВВТ - ейтонія за нормальної ВР, який свідчить про стійку адаптацію, виявлена нами

${ }^{38}$ Сергета І.В., Мостова О.П. Особливості перебігу процесів психофізіологічної адаптації та формування психофізіологічних функцій організму учнів сучасної школи. Актуальні проблеми транспортної медицини. 2013. Т. 32. № 2. С. 84. 
у 20,2 $\pm 3,6 \%$ дітей, що узгоджується з дослідженнями інших авторів ${ }^{39}$. Напруження механізмів адаптації, яке характеризується перевагою тонусу симпатичного відділу ВНС: ВВТ - симпатикотонія, нормальна ВР та ВВТ - ваготонія, нормальна ВР виявлені нами у $1,6 \pm 1,1 \%$ та $20,9 \pm 3,6 \%$ обстежених дітей відповідно.

Таблиця 1

Частота спостережень різної вегетативної реактивності

в дітей 3 різним вихідним вегетативним тонусом $(\% \pm m), n=129$

\begin{tabular}{|l|c|c|c|c|}
\hline \multirow{2}{*}{$\begin{array}{c}\text { Вегетативна } \\
\text { реактивність }\end{array}$} & \multicolumn{4}{|c|}{ Вихідний вегетативний тонус } \\
\cline { 2 - 5 } & $\begin{array}{c}\text { Ваго- } \\
\text { тонія }\end{array}$ & Ейтонія & $\begin{array}{c}\text { Симпа- } \\
\text { тикотонія }\end{array}$ & $\begin{array}{c}\text { Гіперсимпа- } \\
\text { тикотонія }\end{array}$ \\
\hline Асимпатикотонічна & $0,8 \pm 0,8$ & $3,9 \pm 1,7$ & $1,6 \pm 1,1$ & $7,8 \pm 2,4$ \\
\hline Симпатикотонічна & $20,9 \pm 3,6$ & $20,2 \pm 3,6$ & $1,6 \pm 1,1$ & $2,3 \pm 1,3$ \\
\hline Гіперсимпатикотонічна & $16,3 \pm 3,3$ & $12,4 \pm 2,9$ & $6,2 \pm 2,1$ & $6,2 \pm 2,1$ \\
\hline Всього & $38,0 \pm 4,3$ & $36,4 \pm 4,3$ & $9,3 \pm 2,6$ & $16,3 \pm 3,3$ \\
\hline
\end{tabular}

BВТ - ейтонія за гіперсимпатикотонічної ВР, ВВТ - симпатикотонія за гіперсимпатикотонічної ВР та ВВТ - гіперсимпатикотонія за гіперсимпатикотонічної ВР, які характеризують перенапруження регуляторних систем, спостерігалися у 24,8 $33,8 \%$ обстежених. Загалом зсув вегетативного балансу в бік симпатичних впливів відзначено нами у $47,3 \pm 4,4 \%$ обстежених.

У $32,6 \pm 4,1 \%$ дітей виявлено незадовільну адаптацію, яка характеризується таким рівнем функціонування вегетативної нервової системи: ВВТ - ваготонія, гіперсимпатикотонічна ВР; ВВТ - ейтонія за асимпатикотонічної ВР; ВВТ - симпатикотонія, асимпатикотонічна ВР; ВВТ - гіперсимпатикотонія, асимпатикотонічна ВР; ВВТ - ваготонія, асимпатикотонічна ВР; ВВТ гіперсимпатикотонія, симпатикотонічна ВР.

Проведений порівняльний аналіз виявив яскраво виражені відмінності ВР у дітей з різним РС3 (рис. 12).

${ }^{39}$ Состояние механизмов адаптации к учебной нагрузке старшеклассников с разным уровнем профессиональной готовности / Г.Н. Даниленко и др. Здоровье ребенка. 2013. № 3(46). С. 35. 


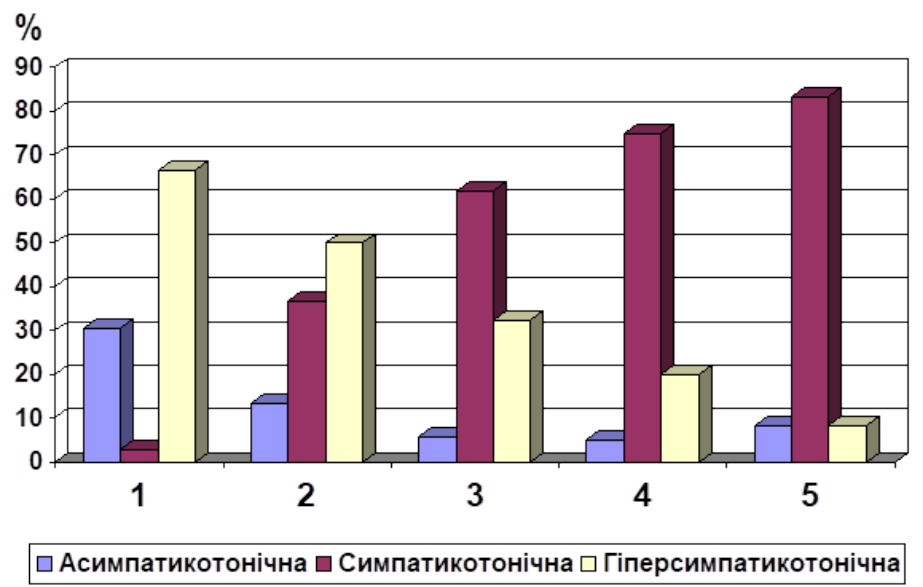

Рис. 12. Вегетативна реактивність у дітей з різним рівнем соматичного здоров'я; рівні здоров'я:

1 -низький, 2 - нижче середнього, 3 -середній, 4 - вище середнього, 5 - високий

Значні відхилення від норми вегетативної регуляції спостерігалися у групі дітей 3 низьким РС3, в якій лише $3,0 \pm 3,0 \%$ дітей мали нормальну (симпатикотонічну) ВР проти $83,4 \pm 11,2 \%$ у групі дітей з високим РС3 $(\mathrm{p}<0,001)$. А частка дітей з гіперсимпатикотонічною ВР виявилась вірогідно вищою у групі дітей з низьким РС3, ніж 3 високим його рівнем $(66,7 \pm 8,3 \%$ та $8,3 \pm 8,3 \%$ відповідно, $\mathrm{p}<0,001)$. Аналогічна картина - вірогідно вища частка дітей з нормальною ВР $(\mathrm{p}<0,05)$ та менша -3 асимпатикотонічною і гіперсимпатикотонічною ВР (p<0,001) спостерігалася у дітей з вище середнім РС3 порівняно 3 дітьми з низьким РС3.

Діти із середнім РСЗ також відрізнялися від своїх однолітків 3 низьким його рівнем більшою часткою дітей з нормальною ВР $(61,8 \pm 8,5 \%$ та $3,0 \pm 3,0 \%$ відповідно, $\mathrm{p}<0,001)$ та меншою часткою дітей 3 асимпатикотонічною $(5,9 \pm 4,1 \%$ та $30,3 \pm 8,1 \%$ відповідно, $\mathrm{p}<0,01)$ і гіперсимпатикотонічною $(32,4 \pm 8,1 \%$ та $66,7 \pm 8,3 \%$ відповідно, $\mathrm{p}<0,01)$ ВР.

Отримані нами дані підтверджені результатами проведеного кореляційного аналізу, який виявив вірогідні зв'язки між числовими характеристиками КІГ та РСЗ, морфофункціональними показниками, показниками захворюваності. 
Так, установлені вірогідні позитивні зв'язки між РС3 та числовими характеристиками КІГ: 3 показниками Мо ( $\mathrm{r}=0,46$, $\mathrm{p}<0,001), \Delta \mathrm{x}(\mathrm{r}=0,37, \mathrm{p}<0,001)$, негативні - 3 АМо $(\mathrm{r}=-0,55, \mathrm{p}<0,001)$, $\mathrm{IH}(\mathrm{r}=-0,37, \mathrm{p}<0,001)$. Наявні вірогідні зв'язки між АМо та індексом Руф'є $(\mathrm{r}=-0,43, \mathrm{p}<0,001)$.

Проаналізовані кореляційні зв'язки значень числових характеристик КІГ з рівнем соматичного здоров'я ще раз підтвердили, що чим нижчий рівень енергозабезпечення організму дитини, тим нижчі адаптаційні можливості організму та більш імовірний розвиток хронічного захворювання. Для дітей з низьким рівнем соматичного здоров'я в порівнянні із середнім та високим виявлено достовірне зменшення $\mathrm{M}_{0}$ та $\Delta \mathrm{x}$, що свідчить про низьку активність парасимпатичного відділу. Виявлене збільшення $\mathrm{AM}_{0}$ свідчить про високу активність симпатичного відділу вегетативної нервової системи в дітей з низьким рівнем соматичного здоров'я. Збільшення інтегрального індексу напруження, вегетативного показника ритму та індексу вегетативної рівноваги в цієї категорії дітей характеризують високу напругу регуляторних систем організму (активацію центрального контуру регуляції). Отримані нами дані вказують на зсув вегетативного балансу в бік переваги тонусу симпатичного відділу в дітей з низьким рівнем соматичного здоров'я.

Також проведені нами дослідження показали, що по мірі зростання рівня соматичного здоров'я підсилюються вагусні впливи на серцевий ритм. Доказом цього є вірогідне зниження індексу вегетативної рівноваги, вегетативного показника ритму та збільшення варіаційного розмаху $(\mathrm{p}<0,001)$. Крім того, менш напруженими ставали компенсаторні механізми організму (зниження IH).

Оцінка вегетативної реактивності дозволила охарактеризувати спрямованість та ступінь змін функціонування вегетативної нервової системи й виявити особливості адаптаційних реакцій обстежених дітей. Встановлено, що тільки п'ята частина $(20,2 \pm 3,5 \%)$ дітей мала збалансований рівень регуляторних систем організму, а третя частина $(32,6 \pm 3,8 \%)$ знаходиться в стані незадовільної адаптації. У 47,3 $\pm 4,4 \%$ спостерігалось напруження та перенапруження регуляторних систем організму.

Отже, комплексне клінічне обстеження дітей водночас iз кількісним визначенням рівня соматичного здоров'я 3 урахуванням стану ВНС надасть можливість визначити ранні ознаки порушень 
адаптаційно-пристосувальних механізмів та виявити зміни стану здоров'я на донозологічному рівні.

\section{ВИСНОВКИ}

1. Отримані результати свідчать про те, що $38,8 \%$ та $22,7 \%$ обстежених дітей пубертатного періоду мають низький та нижче середнього рівні соматичного здоров'я відповідно, середній рівень $-27,2 \%$, вище середнього і високий рівні були притаманні лише $6,6 \%$ та 4,6\% обстежених відповідно. Слід зазначити, що у хлопців показники рівня соматичного здоров'я кращі, ніж у дівчат. У зв'язку з цим, на нашу думку, виникає необхідність удосконалення навчального процесу 3 фізичного виховання в загальноосвітніх навчальних закладах, а саме посилення рівня організації фізкультурно-оздоровчих заходів у системі самостійних занять $з$ фізичного виховання школярів.

2. Зміни вегетативного гомеостазу в дітей пубертатного періоду мають зв'язок із рівнем соматичного здоров'я. Так, за низького та нижче середнього рівнів соматичного здоров'я у більшості дітей переважає тонус симпатичної ланки вегетативної нервової системи 3 підвищенням центрального контуру регуляції (відповідно 60,3\% та $52,5 \%$ ). За підвищення рівня соматичного здоров'я підсилюються вагусні впливи на серцевий ритм, та ймовірно змінюється енергетика міокарду, про що свідчить вірогідне зниження AMo, IBP та збільшення Мо і $\Delta x$. Крім того, менш напруженими ставали компенсаторні механізми (вірогідне зниження $\mathrm{IH}$ ). У групі дітей із високим рівнем соматичного здоров'я частка дітей із ваготонією становить 83,3\%. Зі зниженням рівня соматичного здоров'я гіперсимпатикотонічний варіант вегетативної реактивності змінювався на асимпатикотонічний.

3. В умовах спокою нормотонічний та помірно ваготонічний типи ВНС свідчать про оптимальний стан центральних та автономних механізмів регуляції.

4. Оцінка стану вегетативного гомеостазу та кількісна оцінка рівня соматичного здоров'я буде надзвичайно важливим і необхідним етапом в оптимізації роботи практичного лікаря з метою прогнозування хвороби та персоналізованого підходу до лікування. 


\section{АНОТАЦІЯ}

Представлена робота присвячена дослідженню стану автономної нервової регуляції школярів та його ролі у формуванні стану соматичного здоров'я. На основі авторських досліджень показаний взаємозв'язок стану вегетативного гомеостазу з рівнем енергозабезпечення організму в дітей пубертатного періоду для визначення його впливу на формування адаптаційних механізмів. Так, за низького та нижче середнього рівнів соматичного здоров'я в більшості дітей переважає тонус симпатичної ланки вегетативної нервової системи з підвищенням центрального контуру регуляції (відповідно 60,3\% та 52,5\%). Це демонструє напруження механізмів адаптації серцево-судинної системи та значне зниження рівня адаптаційно-пристосувального потенціалу. У разі підвищення рівня соматичного здоров'я підсилюються вагусні впливи на серцевий ритм і у групі дітей із високим рівнем соматичного здоров'я частка дітей із ваготонією становить 83,3\%. В умовах спокою нормотонічний та помірно ваготонічний типи вегетативної нервової системи свідчать про оптимальний стан центральних та автономних механізмів регуляції.

Оцінка стану вегетативного гомеостазу та кількісна оцінка рівня соматичного здоров'я буде надзвичайно важливим і необхідним етапом в оптимізації роботи практичного лікаря 3 метою прогнозування хвороби та персоналізованого підходу до лікування.

\section{ЛІТЕРАТУРА}

1. Апанасенко Г.Л. Эволюция биоэнергетики и здоровье человека. Петрополис, 1992. 123 с.

2. Апанасенко Г.Л., Козакевич В. К. Оценка физического здоровья детей и подростков. Медичний всесвіт. 2004. Т. 4. С. $68-73$.

3. Бабій І.Л., Величко В.І., Венгер Я.І. Адаптаційні можливості школярів. Здоровье ребенка. 2011. № 8 (35). С. 20-24.

4. Баевский Р.М., Иванов Г.Г. Вариабельность сердечного ритма: теоретические аспекты и возможности клинического применения. Москва : Медицина, 2000. 295 с.

5. Баевский Р.М., Черникова А.Г. К проблеме физиологической нормы: математическая модель функциональных состояний на основе анализа вариабельности сердечного ритма. Авиакосмическая и экологическая медицина. 2002. № 5. С. 34-37. 
6. Показники та соціальний контекст формування здоров'я підлітків : монографія / О.М. Балакірєва та ін. ; відп. ред. О.М. Балакірєва. Київ : ЮНІСЕФ, Укр. ін-т соц. досліджень ім. О. Яременка, 2014. 156 с.

7. Барыкина С.В. Здоровьесбережение: системность мер обеспечения. Матер. III всерос. конгресса «Актуальные проблем здоровья детей и подростков и пути их решения». Москва : Издательство НЦЗД РАМН, 2012. С. 59-61.

8. Вакуленко Л.І. Вегетативний статус у дітей із хронічним пієлонефритом на початкових стадіях хронічної хвороби нирок. Здоров'я дитини. 2019. Т. 14. № 2. C. 81-87. DOI: http://dx.doi.org/ 10.22141/2224-0551.14.2.2019.165543

9. Вейн А.М., Вознесенская Т.Г., Воробьева О.В. Вегетативные расстройства. Клиника, диагностика, лечение ; под ред. А.М. Вейна. Москва : ООО «Медицинское информационное агенство», 2003. $752 \mathrm{c}$.

10. Воронцов И.М. Закономерности физического развития детей и методы его оценки. Ленинград : Издательство ЛПМИ, 1986. $506 \mathrm{c}$.

11. Гозак С.В., Єлізарова О.Т. До питання оцінки адаптаційнорезервних можливостей організму дітей шкільного віку в гігієнічних дослідженнях. Гігієна населених місиь. 2012. № 59. C. 285-292.

12. Состояние механизмов адаптации к учебной нагрузке старшеклассников с разным уровнем профессиональной готовности. Здоровье ребенка / Г.Н. Даниленко и др. 2013. № 3 (46). С. 35-40.

13. Европейская стратегия «Здоровье и развитие детей и подростков». Копенгаген : ЕРБ ВОЗ, 2005. 23 с.

14. Оцінка стану здоров'я школярів загальноосвітніх навчальних закладів різного типу. Вісник Сум ДУ. Серія 172 «Медищина» / I.O. Калиниченко та ін. 2012. № 1. С. 172-177.

15. Козакевич В.К., Зюзіна Л.С. Нові підходи до оцінки стану здоров'я дітей шкільного віку. Современная педиатрия. 2016. № 4 (76). С. 44-46.

16. Роль соціально-економічних факторів у формуванні рівня соматичного здоров'я дітей шкільного віку. Wiadomości Lekarskie / В.К. Козакевич та ін. 2018. tom LXXI. nr 3 cz I. C. 537-542.

17. Коровіна Л.Д., Запорожець Т.М., Козакевич В.К. Вплив екзогенних чинників на соматичне здоров'я та автономну нервову 
регуляцію у дітей та молоді : монографія, Полтава : ПОКППІТ «Освітаінфоком», 2019. 188 с.

18. Кузюк Л.Г., Маковкін Ю.А, Ігнатова Т.Б. Адаптаційні можливості організму 3 урахуванням морфо-функціонального розвитку дітей шкільного віку. Современная педиатрия. 2011. № 1 (35). С. 95-98.

19. Вегетативні дисфункції у дітей. Пароксизмальна вегетативна недостатність / В.Г. Майданнік та ін. Київ: Логос, 2017. 300 с.

20. Марушко Ю.В., Гищак Т.В. Проблема діагностики і корекції зниженої толерантності до фізичного навантаження у дітей шкільного віку. Современная педиатрия. 2014. № 7 (63). С. 34-40.

21. Москаленко Н.В., Єлісєєва Д.С. Аналіз рівня соматичного здоров'я дітей старшого шкільного віку. Вісник Чернігівського національного педагогічного університету. 2014. № 118 (3). C. $189-192$.

22. Наказ МОЗ України від 13.09.2013 р. № 802 «Про затвердження критеріїв оцінки фізичного розвитку дітей шкільного віку».

23. Медико-социальные особенности состояния здоровья школьников в Украине. Georgian Medical News / С.Л. Няньковский и др. 2014. № 5 (230). С. 60-65.

24. Пономарьова Л.І. Особливості формування здоров'я сучасних школярів на різних етапах навчання. Здоровье ребенка. 2014. № 2 (53). C. 35-38.

25. Сергета I.В., Мостова О.П. Особливості перебігу процесів психофізіологічної адаптації та формування психофізіологічних функцій організму учнів сучасної школи. Актуальні проблеми транспортної медицини. 2013. Т. 32. № 2. С. 84-93.

26. BenShlomo Y., Kuh D. A life course approach to chronic disease epidemiology: conceptual models, empirical challenges and interdisplinary perspectives. Int. J. Epidemiol. 2002. № 31. P. 285-293.

27. Healthy Living Cambridge Kids: a community-based participatory effort to promote healthy weightand fitness. Obesity.Silver Spring / V.R. Chomitz et al. 2010. № 18 (1). P. 45-53.

28. Moderate-to-vigorous physical activity fromages 9 to 15 years. Jama / P.R. Nader et al. 2008. № 300 (3). P. 295-305.

29. Retter T.D. School-Based Health Centers in Pediatric Practice. Council on School health. Pediatrics. 2012. Vol. 129. P. 387-393.

30. Thompson R.T., Meslin E.M., Braitstein P.K. The vulnerabilities of orphaned children participating in research: a critical review and 
factors for consideration for participation in biomedical and behavioral research. J Empir Res Hum Res Ethics. 2012. Vol. 7(4). P. 56-66.

31. URL: http://www.who.int/school_youth_health/gshi/en/ (дата звернення: 25.11.2015).

\section{Information about the authors:}

Kozakevych V. K., Candidate of Medical Sciences, Assistant at the Department of Pediatrics № 1 with Propaedeutics and Neonatology Ukrainian Medical Stomatological Academy 23, Shevchenko str., Poltava, 36011, Ukraine

Ziuzina L. S., Candidate of Medical Sciences, Associate Professor at the Department of Pediatrics № 1 with Propaedeutics and Neonatology Ukrainian Medical Stomatological Academy 23, Shevchenko str., Poltava, 36011, Ukraine 